\title{
EVALUASI PELAKSANAAN BIMBINGAN DALAM PRAKTIK KETERAMPILAN MENGAJAR TERHADAP MAHASISWA FAKULTAS TEKNIK UNIVERSITAS NEGERI JAKARTA
}

\author{
Daryati $^{1}$ \\ ${ }^{1}$ Dosen PVKB FT UNJ, daryati sr@ymail.com
}

\begin{abstract}
Abstrak
Tujuan penelitian adalah mengevaluasi pelaksanaan bimbingan dari dosen pembimbing dan guru pamong dalam pelaksanaan praktik keterampilan mengajar terhadap mahasiswa Praktik Keterampilan Mengajar FakultasTeknik UNJ. Metode penelitian yang digunakan dalam penelitian ini adalah metode deskriptif. Pengumpulan data dilakukan dengan penyebaran angket kepada guru pamong, dosen pembimbing. Angket juga diberikan kepada mahasiswa PKM sebagai verifikasi. Populasi dalam penelitian ini adalah pembimbing PKM pada semester genap tahun akademik 2011/2012. Sampel dalam penelitian ini adalah 21 dari total 41 dosen pembimbing PKM, sedangkan guru pamong 47 dari total 148 guru pamong. Sedangkan sampel mahasiswa sebanyak 69 dari total 239 mahasiswa peserta PKM. Untuk mengetahui pelaksanaan bimbingan PKM oleh dosen pembimbing maupun guru pamong dilakukan analisis dengan prosentase. Hasil penelitian menunjukkan bahwa dosen pembimbing sebagian besar sudah melaksanakan bimbingan secara baik tetapi kehadirannya ke sekolah masih sangat kurang dari yang seharusnya. Sedangkan guru pamong sudah membimbing secara baik dan benar sehingga dapat mengetahui tahapan perkembangan kemampuan mahasiswa PKM dalam mengajar
\end{abstract}

Kata kunci : Evaluasi, Bimbingan, Mahasiswa PKM

\section{EVALUATION OF TEACHING SKILLS IN PRACTICE GUIDANCE TO STUDENTS FACULTY OF ENGINEERING UNIVERSITAS NEGERI JAKARTA}

\author{
Daryati $^{1}$ \\ ${ }^{1}$ Lecturer of PVKB FT UNJ, daryati sr@ymail.com
}

\begin{abstract}
The purpose of the study is to evaluate the implementation of the guidance of faculty mentors and teacher tutors in the implementation of practice teaching skills to students Practice Teaching Skills to Students the Faculty of Engineering, Universitas Negeri. The research method used in this research is descriptive method. Data was collected by distributing questionnaires to the teacher tutors, lecturers. Questionnaires were also given to students PKM as verification. The population in this study is the supervisor of PKM in the second semester of academic year 2011/2012. The sample in this study was 21 from a total of 41 lecturers PKM, whereas officials teacher 47 of the total 148 teachers tutor. While the student sample as many as 69 of the total 239 students participating in PKM. To determine the implementation of PKM guidance by the supervisor and teacher tutors analyzed by percentage. The results showed that most of the lecturers are either already implementing guidance to school but his presence is still considerably less than it should be. While officials have been guiding teacher is good and right in order to know the stages of the development of students' ability in teaching PKM.
\end{abstract}

Keywords: Evaluation, Guidance, Student Practice Teaching Skills. 


\section{Pendahuluan}

\section{Pembangunan nasional dalam bidang pendidikan merupakan upaya mencerdaskan bangsa dan meningkatkan kualitas manusia Indonesia yang beriman, bertaqwa dan berakhlak mulia menguasai ilmu pengetahuan, teknologi hingga dapat terwujud masyarakat yang maju, adil, makmur dan beradab berazaskan Pancasila dan Undang Undang Dasar 1945.}

Sebagai salah satu lembaga pendidikan, Universitas Negeri Jakarta harus mampu menyediakan tenaga kependidikan yang profesional. Tindak lanjutnya adalah dengan menyelenggarakan program kependidikan yang bertujuan untuk menghasilkan lulusan yang mampu melaksanakan tugas-tugas kependidikan dan keguruan secara mandiri dan kelak setelah selesai akan bekerja sebagai tenaga kependidikan yang profesional.

Untuk mencapai tujuan tersebut diperlukan pengalaman berupa latihan profesional di tempat yang mirip dengan tempat yang kelak para lulusan bertugas. Latihan tersebut ada didalam praktik keterampilan mengajar.

Program Praktik Keterampilan Mengajar wajib diikuti oleh setiap mahasiswa yang mengambil program kependidikan. Latihan keprofesional ini merupakan salah satu komponen kegiatan kurikuler yang memerlukan keterpaduan antara penguasaan materi teori dengan penguasaan materi praktik. Dengan kata lain bahwa Praktik Keterampilan Mengajar merupakan muara dari penguasaan segala komponen kurikulum yang diberlakukan.

Dalam melaksanakan Praktik Keterampilan Mengajar mahasiswa sebagai calon guru dapat mengaplikasikan secara terpadu seluruh pengalaman yang didapat selama mengikuti pendidikan. Seperti dijelaskan dalam Buku Pedoman Praktik Keterampilan Mengajar (PKM) bahwa dalam melaksanakan PKM mahasiswa sebagai calon guru dapat mengaplikasikan secara terpadu seluruh pengalaman yang didapat selama mengikuti pendidikan. Selanjutnya dijelaskan bahwa selain itu juga harus dapat mengenali karakteristik peserta didik dan lingkungannya, mengelola kegiatan belajar mengajar, menguasai teknik penilaian, mendiaknosis serta berkomunikasi dengan bahasa yang baik dan benar. Juga harus mampu mengelola kegiatan kelompok baik yang perorangan maupun klasikal yng didasarkan rasa asih, asah dan asuh.

Kemampuan mahasiswa sebagai calon guru harus mampu mengaplikasikan secara terpadu pengalaman belajarnya pada saat mengikuti perkuliahan kedalam kegiatan PKM. Hal ini merupakan salah satu faktor penting kelak dalam mengemban profesi keguruan dikemudian hari saat mereka memangku jabatan sebagai seorang guru utamanya dalam bidang kejuruan.

Seperti dijelaskan dalam buku Pedoman Akademik Universitas Negeri Jakarta bahwa sebagai tenaga kependidikan yang profesional, lulusan Universitas Negeri Jakarta bidang kependidikan harus memiliki seperangkat kompetensi yang diperlukan oleh seorang guru yang profesional serta dapat menerapkan dalam penyelenggaraan berbagai program kependidikan baik di sekolah maupun di luar sekolah. Adapun menurut Undang-Undang No.14 tahun 2005 tentang guru dan dosen bahwa kompetensi yang harus dimiliki oleh seorang guru meliputi : kompetensi pedagogik, kompetensi kepribadian ,kompetensi sosial dan kompetensi profesional.

Dari penjelasan diatas dapat disimpulkan bahwa kegiatan PKM perlu mendapat perhatian yang sungguh-sungguh secara terpadu, terarah dan terbimbing dari berbagai unsur yang terkait.

Usaha untuk memberikan bimbingan kepada mahasiswa calon guru dalam kegiatan PKM merupakan sesuatu yang mutlak yang harus dilakukan oleh pembimbing dalam hal ini adalah dosen pembimbing dan guru pamong. Salah satu komponen penting dalam proses bimbingan tersebut adalah Supervisi Klinis. Hal ini sangat penting dilakukan mengingat 
mahasiswa sebagai calon guru merupakan orang yang harus dipersiapkan untuk menjadi guru, dimana guru harus menguasai empat kopetensi guru seperti tersebut diatas.

Dalam pelaksanaannya supervisi klinis pembimbing memberikan bantuan bimbingan kepada mahasiswa sebagai calon guru sesuai dengan kebutuhan yang bersangkutan sehingga pada akhirnya mahasiswa calon guru mampu menemukan sendiri kelemahan yang ada pada dirinya dan akhirnya dia mampu untuk meningkatkan dirinya melalui analisis bersama dalam kegiatan supervisi klinis.

\section{Identifikasi Masalah}

Berdasarkan uraian latar belakang yang telah dikemukakan sebelumnya, terdapat beberapa permasalahan yang dapat diidentifikasi sebagai berikut:

1. Apakah bimbingan atau supervisi klinis dari guru pamong kepada mahasiswa PKM sudah berjalan dengan maksimal?

2. Apakah bimbingan atau supervisi klinis dari dosen pembimbing kepada mahasiswa PKM sudah berjalan dengan maksimal?

3. Bagaimanakah pelaksanaan bimbingan atau supervisi klinis dari guru pamong dan dosen pembimbing kepada mahasiswa PKM?

\section{Pembatasan Masalah}

Adapun pembatasan masalah pada penelitian ini adalah dosen Fakultas Teknik yang bertugas menjadi dosen pembimbing PKM dan guru SMK yang bertugas menjadi guru pamong PKM di semester 096 tahun akademik 2011/2012.

\section{Rumusan Masalah}

Berdasarkan latar belakang tersebut diatas, maka selanjutnya dapat dirumuskan permasalahannya sebagai berikut : Sejauh manakah pelaksanaan bimbingan atau supervisi klinis dari guru pamong dan dosen pembimbing pada mahasiswa peserta PKM?.

\section{Tujuan Penelitian}

Tujuan penelitian secara operasional adalah untuk mengetahui sejauh mana pelaksanaan bimbingan atau supervisi klinis dari guru pamong dan dosen pembimbing pada mahasiswa PKM agar dapat berlatih secara maksimal dan kelak dapat menjadikan guru yang profesional:.

\section{Metode Penelitian}

Metode penelitian yang digunakan dalam penelitian ini adalah metode deskriptif. Data didapat dari penyebaran angket kepada pembimbing PKM yang terdiri dari dosen Fakultas Teknik yang bertugas menjadi dosen pembimbing PKM dan guru SMK yang bertugas menjadi guru pamong PKM di semester 096 tahun akademik 2011/2012. Sampel dalam penelitian ini adalah 21 dari total 41 dosen pembimbing PKM/PKM, sedangkan guru pamong 47 dari total 148 guru pamong. Semua sampel diambil secara acak (random sampling).Untuk verifikasi data penulis mengambil data sebanyak 69 mahasiswa dari mahasiswa peserta PKM yang berjumlah 239 mahasiswa.

\section{Pembahasan Hasil Penelitian}

Pada masa observasi hampir semua guru pamong telah melakukan pembimbingan mulai dari awal kegiatan PKM di sekolah (94,2\%). Hal ini sangat membantu mahasiswa dalam memperoleh data-data tentang keadaan fisik sekolah, keadaan lingkungan sekolah, fasilitas sekolah, penggunaan sekolah serta interaksi dengan guru-guru dan karyawan di sekolah. Sedangkan guru pamong yang tidak membimbing dalam masa observasi hanya $5,8 \%$, ini berati bahwa hanya sebagian kecil dari guru pamong yang tidak melaksanakan pembimbingan pada awal pembimbingannya. Untuk itu pihak Fakultas Teknik perlu memberitahukan 
kepada dosen pembimbing agar mengingatkan kepada guru pamong untuk dapat membimbing mahasiswanya sejak awal kegiatan PKM di sekolah.

Guru pamong memperkenalkan mahasiswa PKM ke staf dan karyawan sekolah. Responden yang menjawab ya sebesar 85,5 \% dan tidak sebesar 15,5\%. Hal ini dapat diartikan bahwa sebagian besar guru pamong telah melakukan pembimbingan mulai dari awal kegiatan PKM di sekolah terutama saat kegiatan observasi non mengajarnya. Dengan diperkenalankannya mahasiswa PKM kepada staf dan karyawan, diharapkan mahasiswa dapat berinteraksi secara baik dan dapat menanyakan data-data sekolah dengan lengkap seperti : jumlah guru, jumlah siswa, jumlah siswa secara keseluruhan dan hal-hal lain yang diperlukan oleh mahasiswa. Hanya sebagian kecil 15,5\% dari guru pamong yang tidak memperkenalkan mahasiswa PKM ke staf dan karyawan sekolah. Artinya hanya sebagian kecil guru pamong yang tidak melaksanakan pembimbingan pada awal pembimbingannya. Untuk itu pihak Fakultas Teknik perlu memberitahukan kepada dosem pembimbing agar mengingatkan kepada guru pamong untuk dapat membimbing mahasiswanya sejak awal kegiatan PKM di sekolah secara baik.

Mahasiswa mengobservasi di kelas saat guru pamong mengajar. Responden yang menjawab ya sebesar $92,8 \%$ dan tidak sebesar 7,2\%. Hal ini dapat diartikan bahwa hampir semua guru pamong telah diobservasi oleh mahasiswa PKM pada saat mengajar. Pada saat observasi mengajar memang seorang guru pamong harus siap diobservasi oleh mahasiswa bimbingannya dengan maksud agar mahasiswa mengetahui bagaimana menerapkan kedelapan kompetensi dasar mengajar secara riil. Akan tetapi masih ada guru pamong yang tidak diobservasi oleh mahasiswa PKM pada saat mengajar. Bagaimanapun cara mengajar guru pamong harus diobservasi oleh mahasiswa PKM dan kalau ternyata cara mengajar guru pamong belum baik maka guru pamong juga dapat berusaha untuk memperbaikinya.

Guru pamong mengharuskan mahasiswa PKM menyusun RPP sebelum mengajar. Responden yang menjawab ya sebesar $100 \%$ dan tidak sebesar $0 \%$.

Hal ini dapat diartikan bahwa semua guru pamong sudah mengharuskan mahasiswa PKM membuat RPP sebelum mengajar. Hal ini agar apa yang akan diajarkan oleh mahasiswa PKM sesuai dengan ketentuan yang telah ditetapkan di sekolah tersebut.

Semua guru pamong memeriksa RPP. Hal ini dapat diartikan bahwa semua guru pamong sudah membimbing mahasiswa pada saat penyusunan RPP. Meskipun mahasiswa PKM sudah pernah latihan membuat RPP baik pada saat mengikuti mata kuliah Kompetensi Pembelajaran maupun pada saat kegiatan Pembekalan PKM, tetapi mahasiswa tetap harus dibimbing karena ada kemungkinan bentuk RPPnya berbeda dengan apa yang mereka telah dapatkan sebelumnya. Bimbingan yang dilakukan bisa dengan memberikan contoh RPP yang berasal dari sekolah tersebut atau memperlihatkan RPP yang telah dibuat sebelumnya oleh guru pamong. RPP yang dibuat oleh mahasiswa memang harus diperiksa karena dalam hal membuat RPP mahasiswa belum berpengalaman dan baru taraf latihan.

Selanjutnya dalam hal Guru pamong mengomentari RPP, responden yang menjawab ya sebesar 97,1 \% dan tidak sebesar 2,9\%. Hal ini dapat diartikan bahwa sebagian besar guru pamong mengkoreksi RPP yang dibuat oleh mahasiswa PKM. Dalam pelaksanan PKM mahasiswa sedang dalam taraf latihan mengajar, juga dalam menyusun RPP. Oleh karena itu RPP yang dibuat sangat perlu untuk diperiksa selanjutnya diberi komentar sebagai masukan mahasiswa PKM memperbaikinya. Untuk guru pamong yang tidak memberikan komentar RPP yang dibuat mahasiswa PKM yang hanya sebagian kecil $2,9 \%$, ini kemungkinan karena terlalu banyak kegiatan sehingga mempercayakan 
persiapan mengajarnya kepada mahasiswa PKM.

Selanjutnya dalam hal guru pamong menilai setiap RPP yang dibuat oleh mahasiswa. Responden yang menjawab ya sebesar $95,7 \%$ dan tidak sebesar 4,3\%. Hal ini dapat diartikan bahwa sebagian besar guru pamong sudah memeriksa dan selanjutnya memberikan nilai terhadap RPP yang sudah dibuat oleh mahasiswa. Guru pamong harus melakukan tahapan ini agar mengetahui bagaimana kemajuan atau peningkatan prestasi mahasiswa yang menjadi bimbingannya. Dalam kegiatan ini ada sebagian kecil yaitu 4,3\% yang tidak memberikan penilaian terhadap RPP yang dibuat mahasiswa PKM. Hal ini kemungkinan karena mahasiswa tidak memberikan format penilaian harisn kepada guru pamong, sehingga dapat diatasi dengan cara mahasiswa menyodorkan lembar penilaian hariannya kepada guru pamong agar dinilai.

Lebih lanjut semua guru pamong menugaskan mahasiswa untuk mencari materi pembelajaran. Hal ini dapat diartikan bahwa semua guru pamong sepertinya mengharapkan agar materi yang akan diberikan oleh mahasiswa PKM dapat lebih lengkap dan lebih up to date sehingga semua guru pamong menugaskan mahasiswa untuk mencari materi pembelajaran. Tindakan ini sudah cukup tepat agar materi yang diperoleh oleh siswasiswanya tidak ketinggalan jaman.

Selanjutnya semua mahasiswa mengkonsultasikan uraian materi ke guru pamong sebelum ditampilkan. Hal ini dapat diartikan bahwa semua mahasiswa PKM mengkonsultasikan uraian materi yang telah dibuat kepada dosen pembimbing. Setelah mahasiswa membuat RPP maka selanjutnya membuat kelengkapannya khususnya uraian materinya. Hal ini tentu harus dikonsultasikan kepada guru pamong sehingga materi yang akan diajarkan sesuai dengan yang seharusnya dan tidak ada yang tertinggal. Dengan disetujuinya uraian materi oleh guru pamong, maka diharapkan tidak ada materi yang tertinggal dan selanjutnya akan menjadikan mahasiswa lebih mantap dalam mengajar atau dengan kata lain lebih percaya diri.

Pada saat pertama tampil mengajar, guru pamong berada di dalam kelas.

Responden yang menjawab ya sebesar 91,3 $\%$ dan tidak sebesar $8,7 \%$. Hal ini dapat diartikan bahwa sebagian besar guru pamong berada di dalam kelas saat mahasiswa PKM pertamakali mengajar. Hal ini menandakan bahwa guru pamong sebagian besar sudah melakukan tugas terbimbingnya pada mahasiswa. Kegiatan ini juga berada dalam kegiatan supervisi klinis yang dilakukan oleh guru pamong. Tetapi ada sebagian kecil guru pamong yang tidak berada didalam kelas, hal ini perlu ditindakan lanjuti.

Guru pamong mengajak mahasiswa mengikuti rapat jurusan. Responden yang menjawab ya sebesar 43,5\% dan tidak sebesar 56,5\%. Hal tersebut dapat diartikan bahwa sebagian besar guru pamong tidak melibatkan mahasiswa dalam rapat jurusan. Hal ini dikarenakan guru pamong tidak mempunyai wewenang untuk menentukan peserta rapat atau kemungkinan lain karena permasalahan yang akan dibahas dalam rapat bersifat rahasia. Adapun sebagian kecil guru pamong mengajak mahasiswa mengikuti rapat, hal ini sangat baik guna melatih mahasiswa dalam menyelesaikan permasalahan sekolah.

Guru pamong mengajak mahasiswa terlibat dalam kegiatan administrasi sekolah. Responden yang menjawab ya sebesar 65,2 $\%$ dan tidak sebesar $34,8 \%$.

Hal tersebut dapat diartikan bahwa sebagian guru pamong mengajak mahasiswa terlibat dalam kegiatan administrasi sekolah. Hal ini sangat baik agar mahasiswa berpengalaman dalam menyelesaikan administrasi guru seperti: membuat soal UTS dan UAS, mengolah nilai, memasukkan nilai dalam buku dan lain sebagainya. . Akan tetapi ada sebagian kecil yang tidak melibatkan, hal ini kemungkinan guru pamong tidak mau ribet dalam menyelaikan tugasnya sebagai guru.

Guru pamong mengajak membantu kegiatan kewalikelasan. Responden yang 
menjawab ya sebesar $55,0 \%$ dan tidak sebesar 45,0 \%. Hal ini dapat diartikan bahwa sebagian guru pamong yang mengajak mahasiswa untuk membantu kegiatan kewalikelasan dan sebagian lagi tidak mengajak mahasiswa PKM membantu kegiatan kewalikelasan. Kegiatan kewalikelasan bukan tugas utama yang harus dikerjakan oleh mahasiswa PKM, akan tetapi kalau memang mahasiswa PKM sudah dilibatkan dalam kegiatan kewalikelasan memasukkan nilai kedalam raport akan merupakan pengalaman yang dapat dijadikan pembelajaran untuk mahasiswa sebagai calon guru.

Guru Pamong mengajak mahasiswa PKM dalam menangani siswa. Responden yang menjawab ya sebesar $92,8 \%$ dan tidak sebesar 7,2\%. Hal ini dapat diartikan bahwa hampir semua guru pamong mengajak mahasiswa PKM ikut menangani siswa. Penanganan siswa menjadi salah satu tindakan dalam rangka pengelolaan kelas. Jadi dengan diajaknya mahasiswa PKM menangani siswa maka diharapkan mahasiswa dapat mengelola kelas secara tepat dan baik.

Guru pamong menugaskan mahasiswa PKM untuk membimbing kegiatan ekstrakurikuler.Responden yang menjawab ya sebesar 30,4 \% dan tidak sebesar 69,6\%. Hal ini dapat diartikan bahwa sebagian besar guru pamong tidak menugaskan mahasiswa PKM untuk membimbing kegiatan ekstrakurikuler. Biasanya ekstrakurikuler di sekolah ditangani oleh wakil kepala sekolah bidang kesiswaan, jadi bukan wewenang guru pamong. Akan tetapi ada sebagian kecil guru pamong yang menugaskan mahasiswa PKM untuk membimbing kegiatan ekstrakurikuler. Hal ini kemungkinan guru pamong tersebut merangkap sebagai staf wakil kepala sekolah bidang kesiswaan.

Guru pamong memperkenalkan mahasiswa PKM kepada siswa yang akan diajar.Responden yang menjawab ya sebesar $92,8 \%$ dan tidak sebesar $7,2 \%$.

Hampir semua guru pamong memperkenalkan mahasiswa PKM kepada siswa yang akan diajar. Tindakan ini sudah tepat karena hal ini merupakan salah satu tugas guru dalam membimbing mahasiswa PKM. Diharapkan dengan diperkenalkannya mahasiswa PKM kepada siswa diharapkan dapat terjadi interaksi positif antara mahasiswa PKM dan siswa.

Pada saat mahasiswa mengajar guru pamong berada didalam kelas. Responden yang menjawab ya sebesar $69,6 \%$ dan tidak sebesar 30,4 \%. Hal ini dapat diartikan bahwa sebagian besar guru pamong berada di dalam kelas saat mahasiswa mengajar. Hal ini menandakan bahwa sebagian besar guru pamong sudah melakukan tugas mandiri pada mahasiswa nya. Kegiatan ini juga berada dalam kegiatan supervisi klinis yang dilakukan oleh guru pamong. Tetapi ada sebagian kecil guru pamong yang tidak berada didalam kelas, hal ini perlu ditindakan lanjuti.

Guru pamong mengamati tampilan mengajar mahasiswa. Responden yang menjawab ya sebesar 98,6 \% dan tidak sebesar 1,4\%. Hal ini dapat diartikan bahwa hampir semua guru pamong mengamati tampilan mengajar mahasiswa. Kegiatan ini juga merupakan salah satu tugas terbimbing dari guru pamong utamanya dalam pengamatan latihan praktik mengajar. Dalam kegiatan ini guru pamong juga harus mencatat perkembangan keterampilan mengajar mahasiswa. Tetapi ada sebagian kecil guru pamong yang tidak mengamati tampilan mengajar mahasiswa, hal ini perlu ditindakan lanjuti.

Guru pamong menilai tampilan mahasiswa mengajar. Responden yang menjawab ya sebesar 97,1 \% dan tidak sebesar 2,9\%. Hal ini dapat diartikan bahwa hampir semua guru pamong melakukan penilaian tentang tampilan mahasiswa dalam mengajar. Penilaian ini dilakukan setiap guru pamong mengamati tampilan mengajar mahasiswa sehingga mengetahui perkembangan keterampilan mengajar mahasiswa PKM yang dibimbingnya. Tetapi ada sebagian kecil guru pamong yang tidak menilai tampilan mengajar mahasiswa, hal ini perlu ditindakan lanjuti. 
Guru pamong menginformasikan hasil penilaian kepada mahasiswa. Responden yang menjawab ya sebesar 84,1 $\%$ dan tidak sebesar 15,9\%. sebagian besar guru pamong menginformasikan hasil penilaian mengajar mahasiswa bimbingannya. Supervisi ini dimaksudkan agar mahasiswa mengetahui kemampuan mengajarnya. Tetapi ada sebagian kecil guru pamong yang tidak memberikan informasi hasil penilaian kepada mahasiswa bimbingannya, hal ini perlu ditindak lanjuti.

Guru pamong memberikan umpan balik hasil penilaian kepada mahasiswa PKM. Responden yang menjawab ya sebesar 94,2\% dan tidak sebesar 5,8\%.

Hal ini dapat diartikan bahwa hampir semua guru pamong memberikan umpan balik terhadap hasil penilaian mengajar kepada mahasiswa bimbingannya. Dimaksudkan agar kemampuan mengajarnya dapat diperbaiki sehingga menjadi semakin baik.

Setelah RPP dibuat selanjutnya semua guru pamong mengharuskan mahasiswa PKM membuat media pembelajaran. Hal ini dapat diartikan bahwa semua guru pamong mengharuskan mahasiswa PKM membuat media pembelajaran setelah RPPnya dibuat. Kegiatan ini merupakan kegiatan latihan terbimbing dari tahapan pelaksanaan PKM. Disamping membuat medianya, mahasiswa juga perlu latihan bagaimana menggunakannya sebelum tampil mengajar. Selanjutnya semua guru pamong memeriksa media pembelajaran yang dibuat oleh mahasiswa. Kegiatan ini merupakan kegiatan latihan terbimbing dengan maksud agar mahasiswa memperbaiki atau melengkapi medianya apabila belum lengkap sampai layak untuk ditampilkan.

Guru pamong bersama dosen pembimbing menentukan waktu ujian. Hal ini dapat diartikan bahwa semua guru pamong dalam menetukan waktu ujian menunggu persetujuan dari dosen pembimbing aatau sebaliknya. Disamping itu tugas guru pamong selanjutnya adalah menentukan kelulusan mahasiswa bimbingannya bersama dosen pembimbing.
Dari hasil penelitian yang didapat dari sejumlah angket yang telah diisi oleh dosen pembimbing, selanjutnya akan dibahas sebagai berikut:

Mulai membimbing pada saat kegiatan pembekalan PKM khususnya Micro teaching. Responden yang menjawab ya sebesar $66,7 \%$ dan tidak sebesar 33,3 \%. Hal ini dapat diartikan bahwa sebagian besar dosen pembimbing sudah mulai membimbing pada saat pembekalan PKM. Hal ini juga diperkuat dengan angket mahasiswa PKM sebagai data verifikasi, bahwa hampir keseluruhan dosen pembimbing sudah membimbing dari kegiatan microteaching saat pembekalan. Hal ini diharapkan pada saat pelaksanaan PKM berikutnya dosen pembimbing sudah mengetahui kemampuan mahasiswa bimbingannya. Disamping itu sebagai supervisor seorang dosen pembimbing harus bisa menunjukkan kemampuan dan kemauan dalam membimbing mahasiswa yang merupakan potensi yang harus ada dalam proses supervisi. Dengan dilibatkannya dosen pembimbing pada saat pembekalan PKM diharapkan dapat lebih termotivasi dalam melaksanakan fungsi dan tugasnya sebagai supervisor. Untuk dosen pembimbing yang tidak membimbing dari saat pembekalan diharapkan dapat menambah frekuensi bimbingannya pada saat pelaksanaan PKM tahapan berikutnya..

Datang pada saat pelepasan PKM. Responden yang menjawab ya sebesar 71,4 $\%$ dan tidak sebesar $28,6 \%$. Hal ini dapat diartikan bahwa sebagian besar dosen pembimbing hadir saat pelepasan PKM. Hal ini diperkuat dengan angket mahasiswa PKM sebagai data verifikasi, bahwa hampir keseluruhan dosen pembimbing hadir pada saat pelepasan PKM. Dengan hadirnya dosen pembimbing pada saat pelepasan PKM diharapkan penyerahan mahasiswa ke sekolah tempat PKM dapat segera dilaksanakan. Bagi dosen pembimbing yang tidak hadir pada saat pelepasan diharapkan segera menghubungi mahasiswa bimbingannya dan segera diantar ke sekolah tempat PKM. 
Selanjutnya semua dosen pembimbing mengantarkan mhs PKM ke sekolah tempat PKM Dari angket yang diberikan kepada mahasiswa PKM sebagai data verifikasi, bahwa masih ada dosen pembimbing yang tidak mengantarkan mahasiswanya pada saat pertama kali datang ke sekolah. Bagi dosen pembimbing yang tidak mengantarkan mahasiswanya ke sekolah tempat PKM, diharapkan segera datang ke sekolah agar pihak sekolah dapat segera menugaskan guru-guru sebagai guru pamong sehingga dapat segera dimulai kegiatan PKM berikutnya seperti observasi dan seterusnya.

Dalam hal mengikuti kegiatan penyusunan program kegiatan PKM di sekolah.,responden yang menjawab ya sebesar $85,7 \%$ dan tidak sebesar $14,3 \%$.

Hal ini dapat diartikan bahwa sebagian besar dosen pembimbing mengikuti kegiatan penyusunan program kegiatan PKM di sekolah. Hal ini sangat baik karena dengan dosen pembimbing yang mengikuti kegiatan penyusunan program kegiatan PKM, maka program kegiatan yang disusun dapat disesuaikan dengan program kegiatan yang telah digariskan dalam Buku Pedoman PKM-FT-UNJ.

Dalam hal membimbing penyusunan RPP,responden yang menjawab ya sebesar $66,7 \%$ dan tidak sebesar 33,3\%. Hal ini dapat diartikan bahwa lebih saparoh dari dosen pembimbing telah membimbing mahasiswa PKM dalam menysun RPP. Dari angket yang diberikan kepada mahasiswa PKM sebagai data verifikasi, bahwa masih ada dosen pembimbing yang tidak membimbing pada saat mahasiswa menyusun atau membuat RPP. Dengan dosen pembimbing yang sudah membimbing saat mahasiswa menyusun RPP, maka dosen pembimbing tersebut akan mengetahui RPP yang diberlakukan di sekolah tersebut, karena dengan Kurikulum Tingkat Satuan Pendidikan (KTSP) memungkinkan bentuk RPP dapat bervariasi antara sekolah satu dengan sekolah yang lain.
Memonitor ke dalam kelas pada saat mahasiswa mengajar. Responden yang menjawab ya sebesar $76,2 \%$ dan tidak sebesar 23,8 \%. Hal ini dapat diartikan bahwa lebih separuh dosen pembimbing telah melakukan monitoring ke dalam kelas pada saat mahasiswa mengajar. Sama dengan angket yang diberikan kepada mahasiswa PKM sebagai data verifikasi, bahwa masih ada dosen pembimbing yang tidak memonitor ke dalam kelas pada saat mahasiswa mengajar. Supervisi dalam latihan praktik mengajar sangat membantu mahasiswa dalam meningkatkan kemampuan mengajarnya dengan membantu mengobservasi, merefleksi dan menganalisis tingkah laku mengajarrnya. Betapa pentingnya fungsi dari supervisi tersebut, sehingga sangat disayangkan dosen pembimbing yang tidak melaksanakan supervisi klinisnya.

Dalam hal memberi motivasi kepada mahasiswa PKM, responden yang menjawab ya sebesar $85,7 \%$ dan tidak sebesar 14,3 \%. Hal ini dapat diartikan bahwa sebagian besar dosen pembimbing telah memberikan motivasi kepada mahasiswa PKM.

\section{Kesimpulan}

Berdasarkan hasil penelitian maka dapat ditarik kesimpulan sebagai berikut: Guru pamong dan dosen pembimbing sudah membimbing secara benar, baik pada saat mahasiswa observasi maupun pada saat mempersiapkan perangkat pembelajaran seperti : membuat RPP, menyusun materi pembelajaran sampai membuat media pembelajarannya.

Pada saat mahasiswa mengajar, guru pamong dan dosen pembimbingpun tetap melaksanakan supervisi klinisnya sehingga mengetahui betul tahapan perkembangan kemampuan mahasiswa PKM dalam mengajar.

Pada saat akan menentukan waktu ujian, semua guru pamong minta persetujuan dari dosen pembimbing PKM. 


\section{Saran}

Pada saat observasi dimohon guru pamong untuk bersedia diobservasi dan dalam mempersiapkan perangkat pembelajaran. agar guru pamong mengharuskan kepada mahasiswa PKM untuk mempersiapkannya sebelum mahasiswa mengajar.

Sebelum menentukan waktu ujian, agar guru pamong dan dosen pembimbing dapat melihat secara jeli kemampuan mahasiswa dalam mengajar sehingga diharapkan pada saat ujian mahasiswa betulbetul sudah siap dan agar dapat memperoleh hasil yang maksimum.

\section{Daftar Pustaka}

Fakultas Teknik UNJ, Pedoman Pelaksanaan Praktik Keterampilan Mengajar, Jakarta : Fakultas Teknik UNJ 2009.

Lembaga Akta Mengajar, Pedoman Pelaksanaan Program Pengalaman Lapangan, Jakarta : Universitas Negeri Jakarta, 2004

Unit Pelayanan Teknis PPL UNJ, Pedoman Pelaksanaan Program Pengalaman Lapangan, Jakarta : Universitas Negeri Jakarta, 2004

, Pedoman Kegiatan Akademik, Jakarta : Universitas Negeri Jakarta, 2006

--------, Undang Undang Republik Indonesia No.14 Tentang Guru dan Dosen, Jakarta : CV : Eka Jaya, 2006. 